\title{
Water-retaining polymers on the early growth and quality of bushy cashew (Anacardium humile A. St. Hill) seedlings
}

\begin{abstract}
Antônio Gabriel Ataíde Soares*(D), Ruthanna Isabelle de Oliveira' ${ }^{(0)}$, Thaynara Mota Venança' (D),

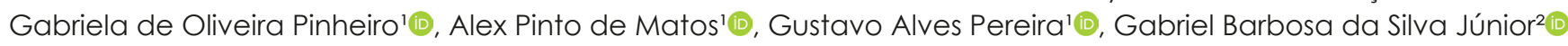

'Federal University of Piaui, Bom Jesus, Brazil

${ }^{2}$ Federal University of Piaui, Teresina, Brazil

*Corresponding author, e-mail: ag.antoniogabriel@gmail.com

\begin{abstract}
Bushy cashew (Anacardium humile A. St. Hill) is an endemic plant species to the Brazilian Cerrado, a region characterized by scarce and poorly distributed rainfall. The use of hydrogel, a water-retaining polymer that features massive water storage and promotes its release into the environment throughout time may be an alternative to reduce the frequency irrigation in the production of bushy cashew seedlings. This study aimed to evaluate the quality and early growth of bushy cashew seedlings as a function of hydrogel doses. The experimental design adopted was in five randomized blocks, with five hydrogel doses $(0 ; 1,0 ; 2,0 ; 3,0 ;$ and 4,0 $\mathrm{g}$ $\mathrm{L}^{-1}$ of soil), and each plot consisting of 10 seedlings, totaling 250 plants. A Yellow Latosol with sandy-loam texture was used for seedling production. The growth evaluation was performed through the variables of emergence speed index, germination percentage, height, diameter, root volume, number of leaves, shoot dry mass, root dry mass, and the Dickson quality index. The results revealed a positive influence of the hydrogel on the growth and quality of bushy cashew seedlings, notably at the dose of $4 \mathrm{~g} \mathrm{~L}^{-1}$ of soil.
\end{abstract}

Keywords: Bushy cashew, hydrogel, seedling production, plant propagation, quality index

\section{Introduction}

The Cerrado biome is characterized for presenting a wide diversity of native fruits, among which the bushy cashew (Anacardium humile A. St. Hill) stands out as a perennial tree species of the family Anacardiaceae, with leafy trees that can reach up to $30 \mathrm{~m}$ in height. There are several uses for this species, especially involving the fruit (shell), to obtain the cashew nut, and with the pseudofruit, which possesses multiple uses in the manufacturing of sweets and drinks or in natura consumption. The plant has already been successfully tested as a rootstock for the precocious dwarf cashew, which may contribute to improving clone yield in cultivation in the Cerrado and areas with marked water deficit (Rufino et al., 2007).

Due to its economic importance in several areas of Northeastern Brazil, the commercial cultivation of bushy cashew has become a common practice. However, the production of seedlings for commercial purposes of a crop with economic potential requires basic information (Zuffo et al., 2014). Among the most important data, the properties of the substrate are highlighted, which should present proper physical, chemical, and biological characteristics that allow the full development of the root system and, consequently, of the shoot (Setubal \& Afonso Neto, 2000; Miranda et al., 2019).

One of the techniques is the addition of waterretaining polymers, or hydrogels, as soil water conditioners aiming at increasing the water retention capacity of substrates for seedling production, providing a better quality (Marques \& Bastos, 2010). Hydrogels are threedimensional polymer networks with the capacity to retain a significant amount of water within its structure, increasing its volume without dissolving, and working as an alternative in occasions when the low availability of water in the soil negatively affects plant growth and development (Mendonça et al., 2015). 
In seed quality determination, both morphological and physiological characteristics can be used, although the morphological characteristics are preferred since they are more accepted by plant growers (Eloy et al., 2013). The evaluation through indices that express relations between growth parameters can be a tool to assess the adequate development and whether the seedlings are within the maximum survival potential after transplantation to the field (Silva et al., 2012). Among the most used data, the Dickson quality index takes into account the shoot, root, and total dry matter production, as well as plant height and hypocotyl diameter (Dickson et al., 1960).

In this perspective, the present work aimed to evaluate the early growth of bushy cashew seedlings as a function of hydrogel doses, as well as the quality index through growth variables.

\section{Material and Methods}

The experiment was conducted in the Federal University of Piauí, Campus Professora Cinobelina Elvas (UFPI/CPCE), Piauí state, Brazil, in a plant nursery belonging to the fruit farming research group of UFPI (FRUTAGRO), with a $50 \%$ shading cloth, located in the municipality of

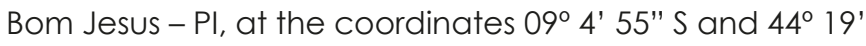
39 " W, with an elevation of $228 \mathrm{~m}$. The region is located in the Brazilian semiarid, where the climate is defined as tropical hot and humid, classified by Köppen as Awa, with two well-defined seasons: a hot season, from May to October, and a rainy season, from November to April (Melo et al., 2015).

The study was performed from September 14 to October 26, 2018. During this period, the data regarding local rainfall were collected, registering an accumulated volume of $51 \mathrm{~mm}$, mean air temperature of $31{ }^{\circ} \mathrm{C}$, and relative air humidity of $36 \%$. The data were obtained from an Automatic Weather Station placed at the University, in cooperation with the National Meteorology Institute, far $150 \mathrm{~m}$ from the plant nursery.

A Latosol with sandy-loam texture was used for seedling production, taken from the educational orchard of the Campus. For the physical-chemical characterization, samples were collected from the 0-20 depth layer, and the analyses were performed according to the methodology described by Teixeira et al. (2017). The mean values of these soil attributes are presented in Table 1.

Table 1. Chemical and physical characterization at the $0-20 \mathrm{~cm}$ depth layer of the Yellow Latosol used in the study.

\begin{tabular}{|c|c|c|c|c|c|c|c|}
\hline $\mathrm{pH}$ & $\mathrm{H}+\mathrm{Al}$ & $\mathrm{Al}$ & $\mathrm{Ca}$ & $\mathrm{Mg}$ & K & SB & $T$ \\
\hline $\mathrm{H}_{2} \mathrm{O}$ & & --- & -1--- & $\mathrm{mol}_{\mathrm{c}} \mathrm{d}$ & 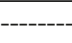 & -a-- & \\
\hline 5.9 & 0.75 & 0.00 & 3.22 & 1.08 & 0.13 & 4.43 & 5.18 \\
\hline $\mathrm{P}$ & $\mathrm{V}$ & $\mathrm{m}$ & O.M. & Clay & Silt & Sand & \\
\hline $\mathrm{mg} \mathrm{dm}^{-3}$ & \multicolumn{2}{|c|}{----- \% ----- } & \multicolumn{4}{|c|}{ - g kg$^{-1}$} & \\
\hline 35.89 & 85.50 & 0.00 & 12.10 & 194 & 64 & 742 & \\
\hline
\end{tabular}

Bushy cashew nuts from native plants were collected at the Gurguéia Farm School (FEAG), belonging to UFPI and based in the municipality of Alvorada do Gurguéia - PI, $08^{\circ} 25^{\prime} 28^{\prime \prime} \mathrm{S}$ and $43^{\circ} 46^{\prime} 38^{\prime \prime} \mathrm{W}$, from the 2018 cropping season and belonging to a single matrix in order to avoid genotype variation in the collected material. After collection, the cashew nuts were taken to the laboratory, where the endocarps free of deformation and/or diseases were selected for sowing.

The experimental design was in five randomized blocks, and the treatments consisted of hydrogel doses in the order of $0 ; 1.0 ; 2.0 ; 3.0$; and $4.0 \mathrm{~g} \mathrm{~L}^{-1}$ of soil, and each plot consisted of 10 seedlings, totaling 250 sampling units.

Black perforated polyethylene bags with capacity for $420 \mathrm{ml}(10 \times 15 \mathrm{~cm})$ were used. Each bag contained soil mixed with the respective hydrogel doses, providing a homogeneous mixture to ensure a good distribution of the polymer in the soil. At sowing, one cashew nut was used per experimental unit, manually placed at a $1 \mathrm{~cm}$ depth. Irrigation was daily performed, according to the requirement of the crop, through a micro-sprinkler irrigation system, with micro-sprinklers located on structures mounted in the ceiling of the plant nursery.

The germination percentage (GP) was evaluated at 16 days after sowing, obtained by counting the number of emerged seedlings for 25 days. Were considered as emerged seedlings all those that presented open cotyledons. The germination percentage (GP) of the seedlings was daily assessed until 25 days of evaluation, and the emergence speed index (ESI) was calculated according to Maguire (1962):

$$
E S I=\frac{N 1}{D Q}+\frac{N 2}{D 2}+\cdots+\frac{N n}{D n}
$$

In which: $E S I=$ emergence speed index; $N=$ number of plants verified on the counting day; $D=$ number of days after sowing in which the counting was performed. 
The following data were measured at the end of the experiment: plant height $(\mathrm{H})$, with the aid of centimeter ruler; base diameter (BD), measured with a digital pachymeter at $2 \mathrm{~cm}$ from the base of the plant, in $\mathrm{mm}$; root volume (RV), determined with the aid of a graduated cylinder containing a known water volume, with the answer being obtained from the direct difference in root volume, through equivalence of units (Basso, 1999); and number of leaves per plant (NF) by visual counting. The shoot and root were separated and dried in forced-air circulation ovens at $65^{\circ} \mathrm{C}$, for 48 hours, for later determination of the shoot dry mass (SDM), expressed in grams, and the root dry mass (RDM), expressed in grams. The sum of both values resulted in the total dry mass (TDM).

For the determination of the seedling quality index, the methodology by Dickson et al. (1960) was used considering the indicators of the root, shoot, and total dry mass, height, and base diameter of the seedlings, through the following equation:

$$
I Q D=\frac{M S T}{\frac{H}{B D}+\frac{S D M}{R D M}}
$$

In which: $D Q I=$ Dickson quality index; $T D M=$ total dry mass, in g; SDM = shoot dry mass, in $g ;$ RDM = root dry mass, in $\mathrm{g} ; \mathrm{H}=$ shoot height, in $\mathrm{cm} ; \mathrm{BD}=$ base diameter, in $\mathrm{mm}$.

The data obtained were subjected to analysis of variance, and for the variables that presented significant differences, a regression analysis was applied in order to verify the behavior of the seedlings in response to the different polymer doses. Pearson's correlation analysis was performed for the variables that constitute the DQI. All the proceedings were performed in the $R$ software ( $R$ Core Team, 2016). The charts were developed in the Microsoft Excel software.

\section{Resultados and Discussion}

Through the analysis of variance, a difference was verified in the growth and quality parameters of the seedlings, evaluated as a function of the hydrogel doses applied (Table 2).

The growth and quality parameters of the bushy cashew seedlings presented a positive linear adjustment with the growing application of hydrogel doses (Figures 1,2 , and 3).

Table 2. Analysis of variance with the mean squares of growth and quality of bushy cashew seedlings subjected to different hydrogel doses in plant nursery conditions, in Bom Jesus, PI.

\begin{tabular}{|c|c|c|c|c|c|c|c|c|c|c|c|}
\hline \multirow{3}{*}{$\begin{array}{l}\text { Variation } \\
\text { source }\end{array}$} & \multirow{3}{*}{ G.L } & \multicolumn{10}{|c|}{ Mean squares } \\
\hline & & \multirow[t]{2}{*}{ ESI } & \multirow{2}{*}{$\begin{array}{c}\text { GP } \\
\%\end{array}$} & \multirow{2}{*}{$\begin{array}{c}\mathrm{H} \\
\mathrm{cm}\end{array}$} & \multirow{2}{*}{$\begin{array}{c}\mathrm{BD} \\
\mathrm{mm}\end{array}$} & \multirow{2}{*}{$\begin{array}{c}\mathrm{RV} \\
\mathrm{cm}-3\end{array}$} & \multirow[t]{2}{*}{$\mathrm{NL}$} & SDM & \multirow{2}{*}{$\frac{\text { RDM }}{\text { g plant-1 }}$} & \multirow[t]{2}{*}{ TDM } & \multirow[t]{2}{*}{ DQI } \\
\hline & & & & & & & & & & & \\
\hline Doses & 4 & $0.0382 * *$ & 904.0* & $8.4748^{*}$ & $0.8947^{* *}$ & $0.0043^{* *}$ & $5.7506^{*}$ & $4.1979 * *$ & $0.6927^{*}$ & $8.2414^{* *}$ & $0.2536 *$ \\
\hline Residue & 16 & 0.0042 & 141.5 & 2.1922 & 0.1473 & 0.0008 & 1.5341 & 0.7582 & 0.2037 & 1.3078 & 0.0341 \\
\hline GM & & 0.40 & 75.60 & 5.89 & 1.79 & 0.09 & 5.15 & 3.79 & 1.64 & 5.44 & 0.96 \\
\hline CV (\%) & & 16.5 & 15.7 & 25.14 & 21.39 & 29.71 & 24.06 & 22.95 & 27.49 & 21.04 & 19.17 \\
\hline
\end{tabular}

SDM: shoot dry mass; RDM: root dry mass; TDM: total dry mass; DQI: Dickson quality index; ** significant at a $1 \%$ level of probability $(p<0.01)$; * significant at a $5 \%$ level of probability $(0.01=<p<0.05)$.

There are studies that show the positive influence of hydrogel in the development of species such as Corymbia citriodora (Bernardi et al., 2012) and Handroanthus ochraceus (Cham.) Mattos (Mews et al., 2015). However, other works have verified negative effects of hydrogel usage. Sousa et al. (2013), using a water-retaining polymer in seedlings of Anadenanthera peregrina verified that although it did not affect shoot development, it negatively influenced seedling quality as the doses increased. Using thirty plant species native to the Atlantic Forest, Barbosa et al. (2013) also found no significant effect of hydrogel usage on seedling survival in the field. These studies are important to assess hydrogel effectivity in different species and environments.

Regarding the emergence speed index, the positive linear behavior showed an increase already at the dose of 1 gram of hydrogel per liter of soil (Figure 1 A). The germination percentage followed the same behavior
(Figure 1 B). According to Carvalho \& Nakagawa (2000), the absorption of water by the seeds leads to the beginning of metabolic processes and decrease of tegument resistance, favoring radicle emission. Thus, when subjected to treatments with hydrogel, which provides greater water availability, the bushy cashew seedlings were favored, accelerating emergence and producing seedlings with better development and greater vigor.

Regarding early growth, the average height of the seedlings presented an increase of up to $2.66 \mathrm{~cm}$ at the hydrogel dose of 4 grams per liter of soil in relation to the treatment without hydrogel (Figure 1C). According to Bernardi et al. (2012), the greatest interest of plant growers is the anticipation of seedling transplantation to the field. In that regard, height is the most used variable, followed by base diameter, as an order of priority for decisionmaking in order to complete the quality evaluation of seedlings. 

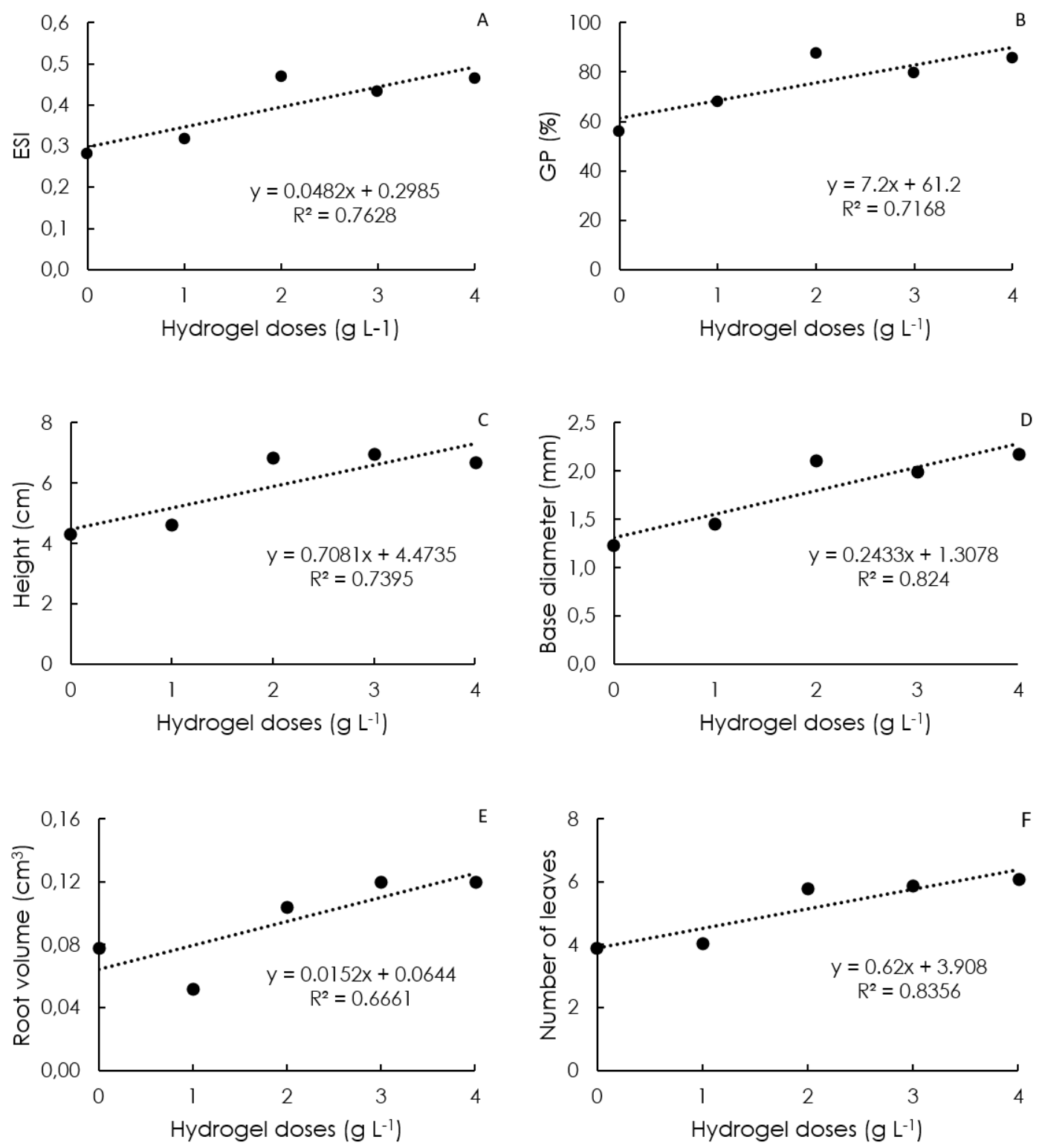

Figure 1. Emergence speed index (A), germination percentage (B), height (C), base diameter (D), root volume (E), and number of leaves (F) in bushy cashew seedlings subjected to different hydrogel doses in plant nursery conditions in Bom Jesus, PI.

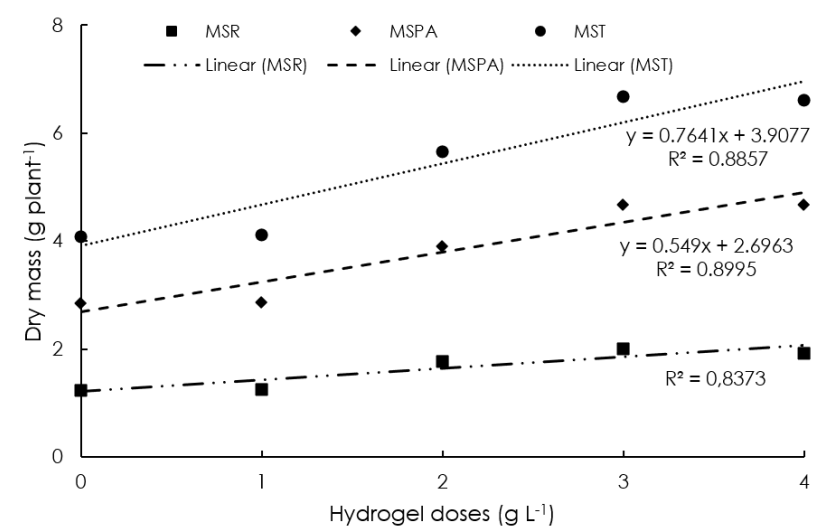

Figure 2. Shoot dry mass (SDM), root dry mass (RDM), and total dry mass (TDM) in bushy cashew seedlings subjected to different hydrogel doses in plant nursery conditions in Bom Jesus, PI.

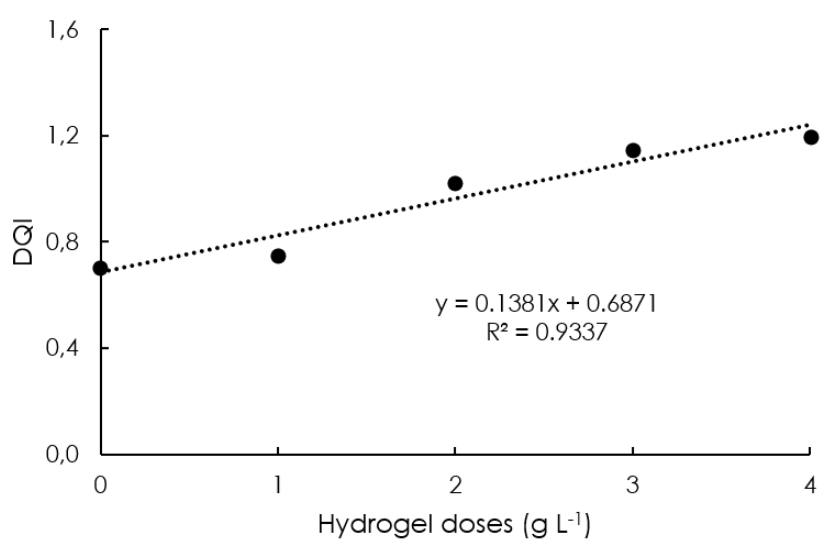

Figure 3. Dickson quality index (DQI) in bushy cashew seedlings subjected to different hydrogel doses in plant nursery conditions in Bom Jesus, PI. 
Based diameter also increased as the hydrogel doses were increased (Figure 1D). According to Navroski et al. (2015), the base diameter should also be larger in seedlings that exhibit greater height so that the tipping of the plant does not occur and, with that, a decrease of the field survival index.

Mews et al. (2015), when evaluating the effect of hydrogel doses (0 to 4 grams of hydrogel per liter of substrate) in the production of seedlings of Handroanthus ochraceus (Cham.) Mattos, obtained increments in the height parameters, reaching maximum growth at the dose of $3 \mathrm{~g}$ of hydrogel, whereas for the base diameter the highest mean value was obtained at the dose of $2 \mathrm{~g}$ of hydrogel.

For the number of leaves, it is observed that the highest value was obtained when using the hydroge dose of 4 grams per liter of soil, reaching a mean of 6.08 (Figure 1E). When the polymer was absent in the soil, a mean of 3.90 was obtained. A larger number of leaves per plant allows greater interception of solar radiation and the performing of the necessary gas exchanges for better seedling development.

The root value increased by $33 \%$ at the hydrogel dose of $4 \mathrm{~g} \mathrm{~L}^{-1}$ of soil in relation to the treatment without hydrogel application (Figure 1F). A larger root volume indicates greater soil exploration and, consequently, a larger volume of water and nutrients. It also contributes to greater support of the shoot part since the height and the base diameter of the seedlings followed the same growing behavior in the present study.

In the measurements of plant growth alterations, dry matter accumulation was characterized as the most significant since it results from the association of several other components, such as reported by Soares et al. (2011). There was an increasing trend for the values as a function of the increment in hydrogel doses for the root, shoot, and total dry masses of bushy cashew seedlings, an increase by 36,39 , and $38 \%$ respectively, at the dose of 4 grams per liter of soil in relation to the absence of the polymer (Figure 2).

Since the $H, B D, N L$, and $R V$ variables obtained a similar behavior, an increase in dry mass production was expected in the seedlings with the growing doses of hydrogel. Menegatti et al. (2017), evaluating the formation of seedlings of Aspidosperma parvifolium A. DC. subjected to different doses of hydrogel and Osmocote $\AA$ in plant nursery conditions, observed that the hydrogel dose of $3 \mathrm{~g}$ provided $\mathrm{s}$ higher production of the shoot, root, and total dry mass, indicating a higher field survival probability by the seedlings.

As hydrogel was increasingly incorporated into the soil, the better was the quality of seedlings in the present study (Figure 3). Navroski et al. (2015), working with seedlings of Eucalyptus dunnii and hydrogel doses found DQI values reaching the maximum point when using a hydrogel dose of $4.6 \mathrm{~g} \mathrm{~L}^{-1}$. Generally, higher values of the Dickson quality index (DQI) indicate more vigorous seedlings and, consequently, with better quality (Zuffo et al., 2014) since several important parameters are considered in its calculation for quality evaluation, such as the robustness and the balance of biomass distribution in the seedling (Fonseca et al., 2002).

Pearson's correlations were performed between the growth parameters and the DQI (Table 3). There was a very strong correlation between the RDM and the DQI, in the present work $(r=0.94)$, with these being the variables with the highest correlation indices. High correlations between RDM and DQI were also observed in other works (Binotto et al., 2010; Pereira et al., 2018; Gomes Júnior., 2018). This behavior is of great importance since it provides an estimation of survival and establishment in the field (Hermann, 1964; Gomes Júnior., 2018).

Table 3. Pearson correlation coefficient between the Dickson quality index (DQI), height (H), base diameter (BD), root dry mass (RDM), shoot dry mass (SDM), and total dry mass (TDM) in bushy cashew seedlings in plant nursery conditions in Bom Jesus, PI.

\begin{tabular}{|c|c|c|c|c|c|c|}
\hline & $\mathrm{H}$ & $B D$ & RDM & SDM & TDM & DQI \\
\hline $\mathrm{H}$ & - & & & & & \\
\hline$B D$ & $0.87^{* * *}$ & - & & & & \\
\hline RDM & $0.84^{* * *}$ & $0.77^{* * *}$ & - & & & \\
\hline SDM & $0.80^{* * *}$ & $0.71^{* * *}$ & $0.67^{* * *}$ & - & & \\
\hline TDM & $0.88^{* * *}$ & $0.79^{* * *}$ & $0.84^{* * *}$ & $0.97^{* * *}$ & - & \\
\hline DQI & $0.82^{* * *}$ & $0.88^{* * *}$ & $0.94^{* * *}$ & $0.79 * * *$ & $0.90^{* * *}$ & - \\
\hline
\end{tabular}

The results obtained indicate that the use of hydrogen incorporated into the soil favored the growth and quality of seedlings of Anacardium humile A. St. Hill when compared to the control treatment. However, more studies using water-retaining polymers should be performed in native species and different environments since they could present divergent results with the use of the product. In the case of the present study, due to the positive result with the increase of the doses, future studies should be performed with doses above $4 \mathrm{~g}$. 


\section{Conclusions}

Hydrogel incorporation positively influenced the early growth and the seedling quality index of bushy cashew seedlings as the doses of the polymer were increased.

The root dry mass was the variable that best correlated with the Dickson quality index in the bushy cashew seedlings.

\section{References}

Barbosa, T.C., Rodrigues, R.R., Couto, H.T.Z. 2013. Tamanhos de recipientes e o uso de hidrogel no estabelecimento de mudas de espécies florestais nativas. Hoehnea 40: 537- 556.

Basso, S.M.S. 1999. Caracterização morfológica e fixação biológica de nitrogênio de espécies de Adesmia DC e Lotus L. 268 p. (Thesis) - Federal University of Rio Grande do Sul, Porto Alegre, Brasil.

Bernardi, M.R., Júnior, M.S., Daniel, O., Vitorino, A.C.T. 2012. Crescimento de mudas de Corymbia citriodora em função do uso de hidrogel e adubação nitrogenada. Revista Cerne 18: 67-74.

Binotto, A.F., Dal' Col Lúcio, A., Lopes, S.J. 2010. Correlations between growth variables and the dickson quality índex in forest seedlings. Revista Cerne 16: 457-464.

Carvalho, N.M., Nakagawa, J. 2000. Sementes: ciência, tecnologia e produção. FUNEP, Jaboticabal, Brazil. 588 p.

Dickson, A., Leaf, A.L., Hosner, J.F. 1960. Quality appraisal of white spruce and white pine seedling stock in nurseries. The Forestry Chronicle 36: 10-13.

Eloy, E., Caron, B.O., Schmidt, D., Behling, A., Schwers, L., Elli, E.F. 2013. Avaliação da qualidade de mudas de Eucalyptus grandis utilizando parâmetros morfológicos. Floresta 43: 373-384.

Fonseca, E.P., Valéri, S.V., Miglioranza, E., Fonseca, N.A.N. Couto, L. 2002. Padrão de qualidade de mudas de Trema micrantha (L.) Blume, produzidas sob diferentes períodos de sombreamento. Revista Árvore 26: 515-523.

Gomes Júnior, G.A., Pereira, R.A., Sodre, G.A., Gross, E. 2018. Growth and quality of mangosteen seedlings (Garcinia mangostana L.) in response to the application of humic acids. Revista Brasileira de Fruticultura 41: 1-10.

Hermann, R.K. 1964. Importance of top-root ratios for survival of Douglas-fir seedlings. Tree Planters' Notes 64: 7-11.

Maguire, J.D. 1962. Speed of germination-aid in selection and evaluation for seedling emergence and vigor. Crop Science 2: 176-177.

Marques, P.A.A., Bastos, R.O. 2010. Uso de diferentes doses de hidrogel para produção de mudas de pimentão. Pesquisa Aplicada \& Agrotecnologia 3: 53-57.

Melo, V.S., Medeiros, R.M., Sousa, F.A.S. 2015. Impactos do clima urbano em Bom Jesus - PI. In: I Workshop de Recursos Naturais do Semiárido, 2015, Campina GrandePB, Programa de Pós-Graduação no semiárido Brasileiro, $15 \mathrm{p}$.

Mendonça, T.G., Querido, D.C.M., Sousa, C.F. 2015. Eficiência do polímero hidroabsorvente na manutenção da umidade do solo no cultivo de alface. Revista Brasileira de Agricultura Irrigada 9: 239-245.

Menegatti, R.D., Navroski, M.C., Guollo, K., Fior, C.S., Souza, A.G., Possenti, J.C. 2017. Formação de mudas de guatambu em substrato com hidrogel e fertilizante de liberação controlada. Revista Espacios 38: 35.

Mews, C.L., Souza, J.R.L., Azevedo, G.T.O.S., Souza, A.M. 2015. Efeito do hidrogel e ureia na produção de mudas de Handroanthus ochraceus (Cham.) Mattos. Floresta e Ambiente 22:107-116.

Miranda, A.C., Queiroz, A.P.M, Soares, I.E.F., Monte Júnior, F.A.C., Aguiar, C.D., Pereira, G.A. 2019. Production of fig seedlings in alternative substrates in the Upper-Middle Gurgueia region. Comunicata Scientiae 10: 396-401.

Navroski, M.; Araujo, M.M.; Reiniger, L.R.S.; Muniz, M.F.B.; Pereira, O.M. de. 2015. Influência do hidrogel no crescimento e no teor de nutrientes das mudas de Eucalyptus dunnii. Floresta 45: 315-328.

Pereira, R.A., Gomes Júnior, G.A., Rodrigues, E.M., Sodré, G.A., Sacramento, C.K. 2018. Matrix management interfers in yield and quality of cocoa seedlings. Revista Brasileira de Fruticultura 40: 1-8.

R CORE TEAM. 2016. R: A language and environment for statistical computing. R Foundation for Statistical Computing, Vienna, Austria. URL https://www.R-project. org/.

Rufino, M.S.M., Corrêa, M.P.F., Barros, L.M., Alves, R.E., Leite, L.A.S. 2007. Suporte Tecnológico para a Exploração Racional do Cajuizeiro. Embrapa Agroindústria Tropical, Fortaleza, Brazil. 30 p.

Setubal, J.W., Afonso Neto, F.C. 2000. Efeito de substratos alternativos e tipos de bandejas na produção de mudas de pimentão. Horticultura Brasileira 18: 593-594.

Silva, R.F., Saidalles, F.L.F., Kemerich, P.D.C., Swarowsky, A., Silva, A.S. 2012. Crescimento e qualidade de mudas de Timbó e Dedaleiro cultivadas em solo contaminado por cobre. Revista Brasileira de Engenharia Agrícola e Ambiental 16: 881-886.

Soares, L.A.A., Lima, G.S., Brito, M.E.B., Araújo, T.T., Sá, F.V. 2011. Crescimento do tomateiro e qualidade física dos frutos sob estresse hídrico em ambiente protegido. Revista Verde 6: 203-212.

Sousa, G.T.O., Azevedo, G.B., Sousa, J.R.L., Mews, C.L., Souza, A.M. 2013. Incorporação de polímero hidroretentor no substrato de produção de mudas de Anadenanthera peregrina (L.) Speg. Enciclopédia Biosfera 9: 1270-1278.

Teixeira, P.C., Donagemma, G.K., Fontana, A., Teixeira, W.G. 2017. Manual de métodos de análise de solo. 
Embrapa, Brasília, Brazil. 574 p.

Zuffo, A.M., Andrade, F.R., Petter, F.A., Souza, T.R.S., Piauilino, A.C. 2014. Posição e profundidade de semeadura na emergência e desenvolvimento inicial de mudas de Anacardium microcarpum Ducke. Revista Brasileira de Ciências Agrárias 9: 556-561.

Conflict of Interest Statement: The authors declare that the research was conducted in the absence of any commercial or financial relationships that could be construed as a potential conflict of interest.

All the contents of this journal, except where otherwise noted, is licensed under a Creative Commons Attribution License attribuition-type BY. 